УДК: 37.011.3-051 (377+377+37.016)

ЛЮДМИЛА ЛИКТЕЙ, методист, викладач, Івано-Франківський коледж, ДВНЗ "Прикарпатський наџіональний університет імені Василя Стефаника", Україна

ORCID 0000-0001-7348-4286

L.liktej@ukr.net

\title{
РОЗВИТОК МЕТОДИЧНОЇ КОМПЕТЕНТНОСТІ ВИКЛАДАЧІВ ГУМАНІТАРНИХ ДИСЦИПЛІН ЧЕРЕЗ ДИСТАНЦІЙНІ ТЕХНОЛОГІЇ НАВЧАННЯ
}

LIUDMYLA LYKTEI, methodist, teacher of the Ivano-Frankivsk college, Vasyl Stefanyk Precarpathian National University, Ukraine

\section{DEVELOPMENT OF METHOD COMPETENCE OF TEACHERS OF THE HUMANITIES THROUGH DISTANCE LEARNING TECHNOLOGIES}

\begin{abstract}
У статті проаналізовано зміст методичної компетентності викладачів гуманітарних дисциплін педагогічних коледжів. Висвітлено основні методичні підходи щодо викладання навчальних дисциплін: методика української мови, українська мова за професійним спрямуванням, основи культури і техніки мовлення, сучасна українська мова, дитяча література з методикою навчання, іноземна мова за професійним спрямуванням (англійська, німецька, польська) тощо. Визначено роль методичної компетентності у професійному зростанні викладачів, котрі активно застосовують дистанційні та інноваційні технології навчання. Окреслено особливості впровадження дистанційних технологій навчання в сучасну систему освіти. Подано погляди науковців щодо впливу дистанційних технологій навчання на розвиток методичної компетентності викладачів гуманітарних дисциплін. Особливу увагу приділено питанню викладання навчальних дисциплін у педагогічних коледжах, їх обсягу, структурі і якості знань, умінь та навичок, що надаються дистанційно.
\end{abstract}

Ключові слова: дистанційні технології навчання, інноваційна діяльність, методична компетентність, розвиток методичної ком-

(с) Л. Ликтей петентності, викладач гуманітарних дисциплін, студент, педагогічний коледж.

Summary. The content of the method competence of teachers of the humanities in pedagogical colleges is analyzed in the article. The main methodological approaches to the teaching of the disciplines are explained: methodology of the Ukrainian language, the Ukrainian language by professional direction, basics of culture and elocution, modern Ukrainian language, children's literature with teaching methods, foreign language by professional direction (English, German, and Polish), etc. The role of methodological competence in the professional growth of teachers is defined, because they actively use distance and innovative teaching technologies; involvement in methodical activities that are implemented by teaching of professional methods of humanitarian direction is outlined.

Key words: distance learning technologies, innovative activity, and method competence, development of method competence, and teacher of the humanities, student, and pedagogical college.

Мета: проаналізувати та розкрити особливості професійної діяльності педагога за допомогою дистанційних технологій навчання в непередбачуваних умовах, вплив дистанційних технологій на розвиток методичної компетентності викладачів педагогічних коледжів.

Постановка проблеми в загальному вигляді. Сьогодні освітня галузь України потребує нової генерації викладачів, інноваційно орієнтованих фахівців, здатних активно та систематично впроваджувати стратегії сучасних технологій навчання для покращення педагогічної діяльності, безперервного розвитку методичної компетентності. Їм необхідні гнучкість і нестандартність мислення, уміння адаптуватися до швидких змін умов життя, забезпечувати атмосферу благополуччя в групі, керувати ініціативою у спілкуванні, застосовуючи багатий арсенал засобів (Макаренко 2019, с. 19-20). Такими змінами вважаємо як і перехід закладів освіти на дистанційну форму навчання, так і використання технологій дистанційного навчання у зв'язку з непередбачуваними ситуаціями на кшталт карантину, військовими конфліктами тощо.

Аналіз досліджень і публікацій. Зазначимо, що з огляду на важливість означеної теми, теоретикометодичною основою даного дослідження стали питання, які неодноразово привертали увагу вітчизняних і зарубіжних науковців. Проблемі розвитку методичної, зокрема, і професійної компетентності викладачів, у тому числі і викладачів гуманітарних дисциплін педагогіч- 
них коледжів, за допомогою дистанційних технологій навчання у закладах освіти присвячено праці В. Андрущенка, I. Зязюна, I. Ісаєва, В. Кременя, Н. Кузьміної, В. Лозової, В. Лугового, В. Майбороди, I. Підласого, В. Бондаря, Н. Гузій, О. Дубасенюк, Н. Протасової, В. Семиченко, С. Сисоєвої, В. Тесленка та ін. (Кузьмінський, 2011, с.112). Водночас спробуємо розглянути питання методичної компетентності, якою мають володіти викладачі педагогічних коледжів для успішної організації навчання через інноваційно-комунікаційні, дистанційні технології та форми роботи (онлайн-сервіси, освітні платформи, інтернет-ресурси тощо). Комплексного вивчення методичної компетентності викладачів педагогічних коледжів у процесі викладання дисциплін гуманітарного спрямування за допомогою дистанційних технологій у непередбачуваних обставинах досі немає. Однак існує ряд обгрунтувань та характеристик, які чітко регламентують оволодіння навчальними знаннями за дистанційною формою навчання.

Виклад основного матеріалу дослідження. У контексті сучасності особливого значення набуває проблема розвитку методичної компетентності викладачів гуманітарних дисциплін педагогічних коледжів. Зважаючи на останні події, що стали ключовими в Україні та світі, важливості набуває й готовність до роботи в системі інноваційних дистанційних технологій навчання. Задля ефективної підготовки майбутніх учителів розвиток методичної компетентності викладачів $є$ одним 3 першочергових завдань сучасної освітньої парадигми. Поділяємо думку Д. Бодненка, котрий наголошує, що для забезпечення системної, цілеспрямованої, комплексної та ефективної роботи викладача до здійснення дистанційного навчання (вважаємо, що і для використання в освітньому процесі дистанційних технологій навчання) необхідно поєднати організаційний напрям роботи викладача, навчально-методичний напрям підготовленості, інформаційно-комунікаційний напрям, нормативно-правовий та психолого-педагогічний напрями (Бодненко, 2011). Застосування технологій дистанційного навчання дозволяє проводити навчан- ня великої кількості людей та підвищити його якість за рахунок застосування сучасних засобів, об'ємних електронних бібліотек, створити єдине освітнє середовище (Корбут, 2015). Звичайно ж, в умовах карантину, військових дій, епідеміологічної ситуації чи в інших непередбачуваних обставинах належна організація освітнього процесу лягає на плечі не тільки закладу фахової передвищої освіти, а й безпосередньо на самого викладача. У таких випадках учасникам освітнього процесу важливо дотримуватися чітких організаційних і дидактичних заходів, спрямованих на реалізацію змісту освіти, оскільки сам процес базується на принципах науковості, гуманізму, демократизму, ступневості освіти, їі наступності та неперервності, органічного поєднання освітньої та наукової діяльності, у тому числі з використанням IT-технологій, технологій та засобів дистанційного навчання (ПНУ, 2020, c. $5,24)$.

Невід'ємною складовою є навчально-методичний напрям підготовленості викладачів гуманітарних дисциплін педагогічних коледжів, який реалізується через систематичний розвиток та вдосконалення методичної компетентності. Звертаємо увагу на роль викладачів, котрі виконують функції координування освітнього процесу, коригують курс, навчають, консультують, надають методичні поради, навчально-методичні матеріали, що забезпечують повну реалізацію змісту навчальних дисциплін в освітньому процесі та сприяють ефективному засвоєнню студентами матеріалу, реалізації компетентностей набутих дистанційно.

Володіння інформаційно-комунікаційними, інноваційно-педагогічними технологіями, використання їх у своїй діяльності продукують здатність реалізувати зміст освіти дистанційно, розвивають фаховий досвід, педагогічний менеджмент, породжують тісну взаємодію між студентами та викладачами. Тут "спрацьовує" партнерський компонент, де викладач та студент працюють на рівних. Такі умови праці передбачають вміння викладача здійснювати роль провідника, який супроводжує студента освітньою галуззю знань, незалежно від навчальних дисциплін, через призму інноваційної педагогічної діяль- ності, яка, на думку науковця О. Цюняк, заснована на осмисленні практичного педагогічного досвіду, орієнтована на зміну й розвиток освітнього процесу з метою досягнення вищих результатів, одержання нового знання, формування якісно іншої педагогічної практики (Цюняк, 2019, с. 99).

Неабияку роль відіграє нормативно-правововий напрям, оскільки він становить юридичне підгрунтя педагогічної освіти та орієнтує викладачів коледжів на подальше провадження освітньої діяльності. На даному етапі звертаємося до листа Міністерства освіти та науки України від 11 березня 2020 року №1/9-154, де у п. 4 зазначено про проведення навчальних занять за допомогою дистанційних технологій $(M O H, 2011)$. Аналізуючи його, звертаємо увагу на вміння викладачів гуманітарних дисциплін закладів фахової передвищої освіти, зокрема, педагогічних коледжів спілкуватися зі студентами не тільки очно, а й дистанційно, за допомогою глобальної мережі Інтернет, через такі інструменти та технології навчання, як електронна пошта, форум, чат, відеоконференція, блог, середовище Classroom, Viber, вебсторінки та веб-сайти тощо.

Працюючи в середовищі Classroom, за допомогою викладача, який $є$ адміністратором, тьютором, коучером, система постійно надає студентам можливість використання будь-яких форм роботи: опрацювання лекційного матеріалу, практичних завдань, тестів, доступ до електронних підручників, словників, довідників, презентацій тощо. Завдяки цим інструментам відбувається взаємозв'язок між студентом та викладачем. Проведення онлайн-заходів може протікати безпосередньо за обраними напрямами (спеціальностями), усіма видами освітньої діяльності.

Викладач, котрий є адміністратором курсу, несе відповідальність за якість та зміст навчального матеріалу. Ніхто, окрім нього, не може редагувати курс. Лекційні матеріали рекомендовано подавати у форматі PDF після того, як студенти отримають аудіозапис заняття. При проведенні семінарського заняття опрацьовується теоретичний матеріал із застосуванням його на практиці. Обговорюється вивчена тема, до якої студенти готують тези вис- 
тупів на основі виконаних завдань. Під час семінарського заняття за допомогою дистанційних технологій формуються вміння і навички практичного використання теоретичних відомостей шляхом індивідуального виконання завдань, сформульованих безпосередньо в дистанційному курсі навчальної дисципліни чи фахової методики.

Консультування також відбувається дистанційно: студенти систематично отримують відповіді від викладача на конкретні запитання, пояснення певних теоретичних відомостей. Таке спілкування проводимо через чат, форум чи Viber. Соціальні мережі та Viber дозволяють створювати закриті групи, чати, завдяки яким відбувається обговорення тем, завдань, проблем тощо. Усе це певним чином впливає на способи відбору і структуризації змісту навчального матеріалу гуманітарних дисциплін, що суттєво позначається на функціонуванні всієї системи навчання.

Відеоконференція в on-line peжимі проходить у визначений викладачем день та час. Ідеться про один із сучасних способів зв'язку, що дозволяє проводити заняття у "віддалених класах", коли студент і викладач знаходяться на дистанції. Під час відеоконференції обговорення і прийняття рішень, дискусії, захист проєктів відбуваються у режимі реального часу. Усі учасники бачать один одного, викладач має можливість супроводжувати лекцію наочністю та підтримувати регулярний контакт зі студентами.

Варто зауважити, що дистанційні технології навчання мають вплив на всі його чинники, які відповідають за якість освіти. Якість освіти - головна мета, пріоритет розвитку громадянського суспільства. Тому освіта формує особистість у всій їі багатовимірності, а не просто дає знання і професію (Cyxa, 2011, c. 444). На даному етапі необхідний системний підхід до багатошарового розвитку методичної компетентності викладачів. Від цього залежить організація і структурування освітнього процесу, використання методів та організаційних форм роботи під час дистанційних занять, організація інформаційноосвітнього середовища, використання інформаційно-комунікаційних технологій, здатність до проведення критичного аналізу, пошуку необхідних електронних ресурсів, синтезу е-матеріалів та й, зрештою, професіоналізм викладача. Роль "мережевого" викладача полягає в допомозі студентові, стимулюванні до пошуку нових знань 3 навчальної дисципліни, дослідженні їі через "всесвітню павутину". Поділяємо думку С. Мерінової, котра зазначає, що, потрапляючи в цифровий інформаційний простір, той, хто навчається онлайн, використовує як наявні вузли джерел і зв'язків, так i формує персональну навчальну мережу. Пошук розпорошеної в базах даних інформації, відбір і зв'язування її елементів у більш-менш цілісну картину знань та їх поширення здійснюються в онлайн-навчанні не лише індивідуальними зусиллями, а й колективними, тобто за допомогою інших суб'єктів (Мерінова, 2017, с. 95).

Незважаючи на те, що впровадження дистанційних технологій навчання в освітній процес набуло неабиякої актуальності, констатуємо, що воно є далеким до завершення, оскільки з'являються нові сервіси, які практичні у застосуванні, досконаліші, доступніші. На прикладі вивчення гуманітарних дисциплін "Вступ до спеціальності", "Методика української мови", "Дитяча література з методикою навчання", "Основи техніки та культури мовлення", "Іноземна мова за професійним спрямуванням (англійська, німецька, польська)" тощо, через дистанційні технології навчання можемо конкретизувати та аналізувати його недоліки і переваги. До останніх відносимо його вплив на формування методичних процесів у свідомості студентів педагогічних спеціальностей та розвиток методичної компетентності викладачів гуманітарних дисциплін. Використання дистанційних технологій змінює характер та особливості навчальної діяльності студентів, пропагує та активізує самостійну роботу, урізноманітнюючи їі. Такі технології навчання $є$ ефективними, оскільки розвивають ключові компетентності професійної підготовки майбутніх фахівців. Таким чином, застосування дистанційних технологій навчання змінює підхід викладачів гуманітарних дисциплін до організації навчальних занять, переорієнтовуються і функції їхньої методичної компетентності, перевага надається самостійній роботі сту- дента. Водночас, як зазначає Ю. Вінтюк, змінюється структура, ускладнюються форми реалізації навчальної взаємодії, у тому числі контроль знань, самостійна робота студентів, консультаційна робота викладачів. Усе це дозволяє піднести процес підготовки фахівців у ЗВО на рівень сучасних вимог, що відповідає потребам діяльності в ринкових умовах (Вінтюк, 2017, с. 361).

Разом $з$ тим нам імпонує думка Ю. Запорожченко, котра нагадує, що при використанні в освітньому процесі дистанційних технологій навчання існує і ряд недоліків. Одним 3 них, вважає вчена, є постійний дефіцит контакту. Переважна більшість часу відводиться на самостійне опрацювання матеріалу, спілкування між учасниками освітнього процесу обмежене, хоча студент може звернутися до тьютора за консультацією, брати участь у ряді семінарів, дебатів тощо. Вимушена вимогливість до себе, навчання через дистанційні технології потребує самодисципліни, самоконтролю, відповідальності, згуртованості, зрештою, сили волі (Запорожченко, 2008, с. 11). Часто в безмежному інтернет-просторі студент "губить" все це.

Результатом успішного розвитку методичної компетентності викладачів гуманітарних дисциплін та засвоєння знань студентів через дистанційні технології навчання може стати і студія онлайн-освіти Educational Era (https://www.edera.com/. iLearn https:// ilearn.org.ua/), що пропонує безкоштовне і доступне навчання: онлайн-курси 3 основних предметів ЗНО, вебінари, тести, подкасти, матеріали для самопідготовки. Prometheus https:// prometheus.org.ua/ онлайн-платформа курсів України і світу із різних предметів та різноманітних напрямів для викладачів і студентів (учителів та учнів). Цікавою є для студентів педагогічних спеціальностей українська програма каталогу е-підручників, відео, аудіокниг для закладів освіти (http://ukrprog.com/). Вони можуть не тільки аналізувати підручники для дітей молодшого шкільного віку, а й ознайомитися 3 додатковими навчальними джерелами з методики навчання української мови, етики ділового спілкування, української мови за професій- 
ним спрямуванням.

У контексті сучасних змін педагогічна освіта розглядається не лише як окрема унікальна сфера підготовки нової генерації педагогів, але і як винятково важливий ресурс розвитку інтелектуального потенціалу нації. Саме тому педагогічний працівник, котрий хоче відповідати вимогам сьогодення, повинен усвідомити необхідність знань теорії інновацій та інноваційних процесів в освіті (Цюняк, 2019, c. 207).

Висновки та перспективи подальших досліджень. Сучасна педагогічна освіта все більше схиляється до віртуального освітнього середовища. Важливою тут бачиться роль викладачів і студентів як безпосередніх учасників. Навчання за допомогою дистанційних технологій займає чільне місце в системі освіти. Пріоритетним завданням залишаються якість освіти, розвиток методичної компетентності викладачів гуманітарних дисциплін, формування ключових компетентностей у студентів. Налагоджена та цілеспрямована робота у цьому напрямі надає широкі можливості при викладанні фахових методик та навчальних дисциплін гуманітарного спрямування і $є$ необхідною у подальшій роботі викладачів гуманітарних дисциплін педагогічних коледжів, однак, потребує подальшого вивчення та вдосконалення.

\section{СПИСОК ЛІТЕРАТУРИ}

Бодненко, Д. М. (2008). Підготовка викладачів вищого навчального закладу до здійснення дистанційного навчання. (Автореф. дис. канд. пед. наук). Київ.

Вінтюк, Ю. В. (2017). Впровадження інформаційно-комп'ютерних технологій у процес підготовки майбутніх фахових психологів. Молодий вчений, 12 (52).

Запорожченко, Ю. Г. (2011). Дистанційне навчання як провідний засіб інформаційної технологізації системи освіти Ірландії. Взято 3 http://lib.iitta.gov.ua/249/1/

Суха, П. Ю. (2011). Інновації у вищій освіті: проблеми, досвід, перспективи. Житомир : Видавництво ЖДУ ім. І. Франка.

Кузьмінський, А. I. (2011). Педагогіка вищої школи.

Корбут, О. Г. (2015). Дистанційне навчання: моделі, технології, перспективи. Взято $3 \mathrm{http}: / /$ confesp.fl.kpi.ua/node/1123.

Макаренко, Ю. (2019). Розвиток професійної компетентності молодого викладача. Фахова передвища освіта, Вип. 2. Київ : Видавництво науково-методичного центру.

Мерінова, С. В. (2017). Дистанційне навчання як невід'ємний атрибут сучасної освіти. Матеріали міжвузівського вебінару. Взято 3 http://www.vtei.com.ua/images/VN/ 31 03.pdf. Вінниця.

Положення про організацію освітнього процесу та розробку основних документів з організації освітнього процесу в Державному вищому навчальному закладі "Прикарпатський національний університет імені Василя Стефаника". Івано-Франківськ.

Цюняк, О. П. (2019). Педагогічна інноватика. Івано-Франківськ.

Цюняк, О. П. (2019). Професійна підготовка майбутніх магістрів початкової освіти до інноваційної діяльності у контексті ідей І. А. Зязюна. Педагогічна освіта: теорія і практика, Вип. 26 (1-2019), Ч. I, 206-211.

Взято 3 https:// www.slideshare.net/andrewvodianyi/ 19154-11-2020.

\section{REFERENCES}

Bodnenko, D. M. (2008). Preparation of Higher Education Teachers for Distance Learning.( Abstract. diss. Cand. ped. Sciences). Kyiv.

Vintiuk, Yu. V. (2017). The introduction of information and computer technologies in the process of training future professional psychologists. Molodyi Vchenyi
(Young Scientist), 12 (52).

Zaporozhchenko, Yu. G. (2011). Distance learning as a leading tool for information technology in Ireland's education system. Retrieved from http://lib.iitta.gov.ua/249/1/

Sukha, P. Yu. (2011). Innovation in Higher Education: Challenges, Experiences, Prospects. Zhytomyr : Publishing House of Zhytomyr Ivan Franko State University.

Kuzminskyi, A. I. (2011). Pedagogy of high school. Higher education of the 21 st century.

Corbut, O. G. (2015). Distance Learning: Models, Technologies, Perspectives. Retrieved from http:// confesp.fl.kpi.ua/node/1123.

Makarenko, Y. (2019). Development of professional competence of young teacher. Professional Pre-Higher Education, Issue 2. Kyiv : Publishing House of the Scientific and Methodological Center.

Merinova, S. V. (2017). Distance learning as an integral attribute of modern education. Materials of the Intercollegiate Webinar. Retrieved from http://www.vtei.com.ua/images/ VN/31_03.pdf. Vinnytsia.

Regulations on the organization of the educational process and development of basic documents on the organization of the educational process at the State Higher Educational Institution "Vasyl Stefanyk Precarpathian National University". Ivano-Frankivsk.

Tsuniak, O. P. (2019). Pedagogical Innovation. Ivano-Frankivsk.

Tsuniak, O. P. (2019). Professional preparation of future masters of elementary education for innovative activity in the context of Ziaziun ideas. Teacher education: theory and practice, Issue 26 (1-2019), Part I, 206-211.

Retrieved from https:// www.slideshare.net/andrewvodianyi/ 19154-11-2020

Стаття надійшла 15.03.2020 p. 